Yolanda Aixelà-Cabré

\title{
Rise and Fall of the Spanish Colonial Dream in Africa: Former Civilian Colonists' Emotions and their Gendered Experiences Facing African Voices
}

\begin{abstract}
This chapter approaches the Spanish colonization in Morocco and Equatorial Guinea through the experiences and emotions of the Spaniards who migrated to these countries. Emotions of colonial dreams emerged in the narratives of Spanish informants in search of an economic paradise that, with colonial independences, changed into bitterness and imperial nostalgia. These Spanish narratives are confronted with African voices to observe what reality paradise had for subaltern groups. The result of the comparison was shocking because some African voices remembered the colonial past with nostalgia. That point was interpreted as a powerful criticism to their unequal current political systems.
\end{abstract}

Key words: Spanish colonial dream, gendered experiences, nostalgia, Spanish Protectorate of Morocco, Spanish Guinea

Emotions and experiences of the Spanish colonial past in the African territories during the $20^{\text {th }}$ century are the central aim of this chapter. ${ }^{1}$ My concern is to show that the Spanish colonial dream lived by civilians, was to get rich in an economic paradise, ${ }^{2}$ and exemplifies a European dominant narrative in the sense of Appadurai's (1990) ideoscapes. For Appadurai, ideoscapes "have to

\footnotetext{
1 Variations of this text were presented in the International Seminar "'El sueño europeo', o: ¿del sueño americano al europeo?” organized by Verena Dolle at Justus-Liebig-Universität Gießen (Germany) in October of 2018 and at Hispanistentag, Berlin, March 2019. My research has been supported by the Project "Enriching European Cultural Heritage from Cultural Diversity and Collaborative Participation" (2017-2018) (EUIN2017-85108), and by the Research and Development Project titled "African Memories: Reconstructing Spanish Colonial Practices and their Imprint in Morocco and Equatorial Guinea” (2016-2018) (HAR2015-63626-P, MINECO / FEDER, UE), both from the Ministry of Economy-Competitiveness of Spain, and both directed by Y. Aixelà-Cabré.

2 An approach to colonial economic paradise in Africa is offered by Deckard (cf. 2010: 77-129) from Literary Studies.
}

Yolanda Aixelà-Cabré, IMF-CSIC, Barcelona 
do with the ideologies of states and the counter ideologies of movements explicitly oriented to capturing state power or a piece of it” (Appadurai 1990: 299). Here, colonial narratives of Spaniards that lived in the African colonies coincided with the Spanish rhetoric put in circulation to justify colonization.

My work observes Spanish experiences and emotions, comparing them in such different African contexts as Spanish Protectorate of Morocco (Al-Hoceima, Rif, area colonized from 1912 to 1956) and the Spanish Territories of the Gulf of Guinea (Oveng, Bata, region colonized from 1777-1778 to 1968). ${ }^{3}$ The interest is to decode how civilian former colonists, located in the margins of these colonies, thought and lived the Spanish colonial dream in Africa given that research illustrates memory and emotions as inextricably linked, as Delgado, Fernández and Labany (2016) traced to do in contemporary Spanish history. My hypothesis is that Spaniards preeminent position regarding the occupied populations was key to perform the colonial dream: their status determined their positive valorization of Spanish colonization, since these experiences empowered them during their settlement, and when they come back to Spain although it was a bitter return due to the loss of paradise. On the one hand, in their narratives emerged the term nostalgia. This concept was developed by Rosaldo (1989) to criticize the bias of officials, missionaries and ethnographers on their understanding of the consequences of colonization. For Rosaldo imperial nostalgia was "a particularly appropriate emotion to invoke in attempting to establish one's innocence and at the same time talk about what one has destroyed" (Rosaldo 1989: 108). But this double sense was unfrequently in the Spanish narratives. So it is that, it was uncommon to find Spaniards that felt uncomfortable because their advantageous status in these contexts, visible in many ways as their facilities to settle, their extra-rights regarding properties and services, and their authority and power over African populations. Indeed, these factual benefits went in parallel to a Spanish governmental rhetoric that, in a kind of binary and simplistic orientalist

3 This chapter will reproduce voices of Spaniards, Moroccans and Equatorial Guineans to illustrate different topics. My fieldwork is based on former civilian colonizers' memories of men and women. These people, accurately selected, offer a collective memory thanks to the intensive work done with two Spanish families that migrated to Morocco and Equatorial Guinea. They have been object of large interviews from 2015 and 2018, work combined with a deep documental study of personal letters and photographs of private collections and of the Colección Giménez Ferrer (CGF), Institució Milà i Fontanals - CSIC. The approach shows the different motivations that their settlement had for men and women, at the same time that face Spanish experiences to African versions, thanks to my extensive and multi-sited fieldwork between Moroccans and Equatorial Guineans started in the 1991 and in 2004, respectively, carried out until today. 
grammar named "savages" to Equatorial Guineans and "traitors moors" to Moroccans (Aixelà-Cabré 2017: 24).

On the other hand, the memories made visible the gender perspective. It was evidenced Stoler's (1989) affirmation that sex limited the rights and mobility of settlers. For the case studies of Rif region and Bata district, Stoler's observation that most men and women had different responsibilities in the colonies was confirmed: "the majority of European women who left for the colonies in the late 19th and early 20th centuries confronted profoundly rigid restrictions on their domestic, economic and political options, more limiting than those of metropolitan Europe at the time and sharply contrasting the opportunities open to colonial men" (Stoler 1989: 634).

Finally, the chapter will approach the other side of the coin given that the Spanish colonial memories are going to be contested by African population experiences to unveil the harsh reality of Moroccans and Equatorial Guineans behind this dream of paradise. The result to confront versions of the colonial past was shocking when nostalgia appeared in the voices of some African informants. ${ }^{4}$ The most probable reason is that for Africans the Independence did not provide their regions with the sanitary, educational and political improvements they expected. So, this is why their nostalgia has to be understood as a direct and powerful criticism to their unequal current political systems, given that Equatorial Guinea is a dictatorship and Morocco a weak constitutional monarchy.

\section{The rhetoric of conquest: A Spanish colonial dream that came true}

African colonization is repeatedly associated with the rhetoric of conquest. Indeed, the upper military ranks were genuine enthusiasts for the Spanish colonization of Africa and proclaimed the benefits of the territorial conquest. ${ }^{5}$ But the

4 This index of informants provides some fundamental data, and the time and place in which the interviews were conducted. I must specify that I have minimized their personal data, guaranteeing their complete anonymity. My interest is that these people cannot be identified, since oral sources have been subject to ethical commitments, prioritizing the anonymity of the informant and the safeguarding of their identity. People who appear with names and surnames specified that they wanted to be cited with their full name.

5 In the magazine of the Liga Africanista Española, whose patron was King Alfonso XIII, Villanova wrote: "Si la acción de España en Marruecos ha de ser principalmente civilizadora [...]. Históricamente, moralmente, y étnicamente no cabe duda que España reúne condiciones insuperables para esa obra de tutela afectuosa de cordial dirección, de hermano mayor que el Protectorado 
attempts to promote the settlers' establishment with a spirit of adventure, courage and bravery aroused a degree of suspicion among Spanish civil society, who observed the settling of Equatorial Guinea with caution, and that of the Spanish Protectorate with only limited sympathy. These perceptions impacted in the Spanish migrations: the number of civilians that settled in the Spanish Protectorate was bigger than that settled in Spanish Guinea. ${ }^{6}$

The lack of zeal for colonizing the Spanish Territories of the Gulf of Guinea was due, above all, to the significant geographical distance from the peninsula, to a climate with a high risk of contracting supposedly deadly tropical diseases -according to the interviews-, and to a degree of respect for the "nature of its geography and its peoples" ("la naturaleza de su geografía y de sus gentes"), in words of the Spaniard Eduard. ${ }^{7}$ A clear example was the Spanish Irmina Margenat, wife of the main responsible of the coffee plantation in Oveng, Ramon Reig. She wrote her thoughts about their migration to Equatorial Guinea in March 1943, after ten years of settlement: "yo poca cosa tengo para contaros si no es el muchísimo calor que hace en esta bendita tierra tan lejana y tan complicada [...]. Hace pocos días que pasó pánico de una nueva epidemia de fiebre amarilla". 8

The colonial rhetoric described the inhabitants of Guinea as a "savage people" who were to be modernized thanks to Christianization and Hispanicization. In practice, the most violent use of the term "savage" was applied not to the Bubi people of Fernando Pó, who took refuge in the interior of the island after their confrontations with the Spanish, but to the Fang of the mainland, who were accused of anthropophagia (cf. Fernández Moreno 2018: 89-90, Sá 2018:

significa." (Villanova 1922: 1; "Spain's action in Morocco must be first and foremost civilizing [...]. Historically, morally and ethnically there can be no doubt that Spain brings together conditions that are unsurpassed for this work of caring tutelage and cordial guidance, that of the elder brother as the Protectorate implies.” My translation, Y. A.-C.). Archivo General de la Administración de Alcalá de Henares (AGA), Caja M154, signatura (15) 3 81/10132.

6 For example, in the 1950 census, Spaniards were included among the 3.948 recorded white inhabitants in the Spanish Territories of the Gulf of Guinea (Resúmenes Estadísticos 1958: 36). Their number was multiplied by ten in the Spanish Protectorate in the same census: 36.048 Spaniards were living there (Instituto Nacional de Estadística 1952: 333).

7 See above n. 3; more detailed circumstances of the interviews are given in the bibliography. Translations into English from the original sources (interviews and letters) are mine (Y. A.-C.), unless otherwise stated.

8 "I have few things to explain if it is not the great heat of this blessed land, so far and so complicated [...] A few days ago we panicked about a new epidemic of yellow fever". Irmina Margenat. Letter from Oveng-Bata of March 2, 1943. Colección Giménez Ferrer, IMF-CSIC, from now CGF. 
111). It was known that the effective colonization of Fernando Pó (1843-1850) did not encounter great resistance, but, as predicted, the continent was a different matter, meaning it was delayed until 1905 and only consolidated from 1915 onwards. As Eduard, who inherited the plantation of coffee in Oveng, pointed out: "Lo atractivo de la Guinea era la isla, no el continente [donde teníamos nuestra plantación]. [...] [que] tenía muchas pegas por la vegetación, la gente, y el transporte". 9

Because Spain's ambitions in Morocco dated back centuries -and were tangible during the Hispano-Moroccan War (1859-1860 $)^{10}$ - settlers were more willing to establish themselves in the Spanish Protectorate as, for example, Tetouan. For them, Morocco seemed to present a great opportunity after strong Riffian resistance was overcome in the Battle of Annual (1921) and the Republic of the Rif was established (1921-1925). Despite these two Riffian victories over Spanish army, the Moroccans were finally defeated and gave way to Spanish civilians who saw the merit in funds being allocated to maintain a significant number of troops there. This military occupation facilitated the settling of Al-Hoceima with Spaniards from Ceuta, Melilla, Málaga and Almería. As the Spanish Pepe said, as soon of one of the first families to settle in Al-Hoceima: "Spaniards were arriving in conquered lands" ("Fueron llegando españoles a tierras conquistadas" (italics mine, Y. A.-C.).

So, the notion of conquest was indubitably more present in the Protectorate of Morocco than in the Territories of the Gulf of Guinea, as, after five centuries of Muslim presence in Al-Andalus, the "Muslims" -called moros (Moors) by the Spanish- occupied a prominent place in Spain's collective imaginary and its colonial dream. This contrasted with the image of the negros, morenos in the politically correct Spaniards' wording of Equatorial Guinea, whose lesser historical significance was connected to the exploitation of the slave trade and to their mockery in human zoos (cf. Sánchez Gómez 2006).

Morocco constituted a military-political dream fulfilled, ${ }^{11}$ but the Spanish Territories of the Gulf of Guinea at the beginning did not: the justification there seems clearly to have been based on the economic opportunities offered and a revitalizing of colonialism after the losses of Cuba and the Philippines, being after the Spanish Civil War, when the Spanish perception of Equatorial Guinea changed. At home, as Eduard explained, "la conversación era si los niños, mi

9 "What was attractive about Guinea was the island, not the mainland [where we have our plantation], which had many drawbacks due to the vegetation, the people and the transport." 10 It is recommended the work of Goikolea (2018).

11 Calderwood (2018) offers an excellent approach to how contemporary Morocco engaged with Al-Andalus past. 
hermano y yo, podíamos ir a Guinea. Era el sueño del paraíso económico, era la postguerra". 12

This assertion shows the consideration of colonies as land of opportunities, at the same time that emerges the connection between colonial dream and masculinity. This point is confirmed by my interviews to Spanish women in Morocco and the study of their letters from Equatorial Guinea: they haven't expressed their adhesion to the colonized action or there was no enthusiasm for the colonial dream. This does not mean that they had not adapted, benefited or even denied their lives out of Africa, given that many women had an adventurous spirit. It is only that their interest to conquer appeared less pronounced than those of men, probably as effect of the prevailing gender construction promoted during dictatorship times in Spain, characterized by a catholic sexual division in which woman priorities had to be loyal mother and spouse.

In any case, the territorial conquests were more rhetorical than practical because, aside from the fact that the Spanish colonization of Morocco was urban in nature, in contrast to the rural colonization of Equatorial Guinea, the settlers knew that other clearly delimited borders were in place, because their movement ended up being restricted to the area of effective military control which was, in reality, very limited. The Spanish populations were therefore unused to venturing beyond the confines of their cities or properties, except to go to Ceuta, Melilla or Tétouan in the Spanish Protectorate, or to Bata or Santa Isabel in Spanish Guinea. For example, Pepe remembered that he was always in Al-Hoceima, "only once we did an excursion of $40 \mathrm{~km}$ to see the river" ("Sólo una vez hicimos excursión de $40 \mathrm{~km}$ para ver el río”). The security cordon established in the areas where they lived was strong, but was weak in the other that also formed part of the Spanish Protectorate and the Territories of the Gulf of Guinea. This prudence with regard to geographical mobility, which only began to be relaxed towards the end of colonization, provided evidence of the indigenous resistance and resilience, and how fictional the Spanish colonial dream of territorial conquest was.

Spaniards, men and women, remembered their colonial times and their African adventure with nostalgia. Despite the personal efforts and sacrifices that they insisted they faced, being the prominent their migration to unhealthy places with considerable risk of themselves, their sum up was extraordinarily favorable. For example, after Spanish Civil War there was a scarce circulation of foods and

12 "The conversation was whether the children, my brother and I, could go to Guinea. It was the dream of economic paradise in postwar times." 
goods in the peninsula that provoked that part of the Spaniards were hungry. But the Spaniard María, sister of Pepe, proudly remembered that in Al-Hoceima "Allí vivimos muy a gusto, no nos faltó de nada, en la Guerra. Teníamos azúcar de pilón, jabón, embutidos, no faltaba de nada". ${ }^{13}$ As her brother said, "Del 1939 al 1941, el hambre que había en España en Alhucemas no lo había” ${ }^{14}$

\section{Emotions and versions facing the end of the Spanish colonial dream}

Spanish people rejected the changes when colonization was close to its end. After the Autonomous period established by Spain to delay Equatorial Guinea's decolonization, Ramon Reig felt uncomfortable. This period was between 1963 and 1968, year of the Equatorial Guinea's independence. In September 10, 1963, Ramon wrote: "Aquí hay mucho nerviosismo y algo de pánico". ${ }^{15}$

Certainly, his letters to the Catalan partners reflected the strong discomfort and inconvenience felt by him and other Spaniards by sharing power and rights with African populations. Spaniards had to share their key political positions, relevant as source of their authority, with some Equatorial Guineans. This situation implied loss of privileges for white population, something that can be observed between lines in their letters, where the vocabulary to name Africans changed. Negro started to be more common than moreno. Ramon and Irmina's missives offered details about the retreat of the Spaniards that left the country, something that never had happened in the letters. As Ramon stated, "se van marchando cantidad de señoras y boys. Todos los que tienen cuatro cuartos en los bancos los están transfiriendo a España". ${ }^{16}$ Certainly, families started to divide. Spanish colonial dream started to go away. Husbands remained few time more than their wives and children, while Equatorial Guinean domestic boys, left too, as proof of the waning Spanish power. Spaniards had started to think

13 "We lived very comfortably, we did not miss anything during the War. We had pylon sugar, soap, sausages, nothing was missing."

14 "From 1939 to 1941, Spain's hunger was not in Alhucemas." Al-Hoceima received many names such as Villa Sanjurjo, Villa Alhucemas, Alhucemas, and Al-Hoceima in Arabic, Taghzut in Riffian.

15 "There is a lot of nervousness and some panic here." Ramon Reig. Letter from Oveng-Bata of September 10, 1963, CGF.

16 "many ladies and boys are leaving. All those who have money in the bank are doing transfers to Spain.” Ramon Reig. Letter from Oveng-Bata of September 10, 1963, CGF. 


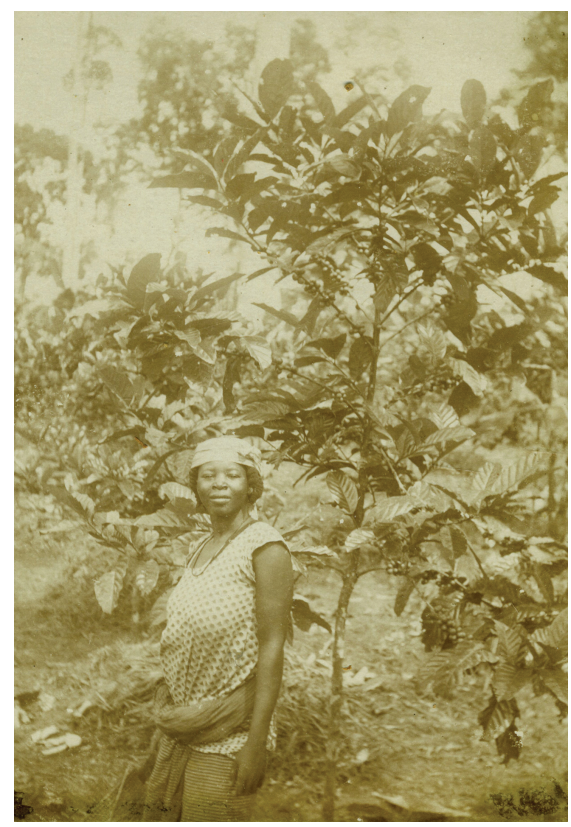

Figure 1: Photograph of a Fang woman in plantation, Equatorial Guinea. Colección Giménez Ferrer (IMF-CSIC).

what they could save of their properties, while the perception of relevant Spaniards, with political representation, regarding Equatorial Guineans was really poor. This was the case of Ramon, who explained in a letter: "[q]uiera dios que yo me equivoque y pudiera durar el régimen autónomo años y que un milagro hiciera aparecer nativos buenos y capacitados". ${ }^{17}$

The establishment of colonial structures had meant the installation of a system of inequalities and hierarchies between the Spanish population and the indigenous that produced strong resentment that was highly notable in Equatorial Guinea, but residual in the Spanish Protectorate, and which gradually faded over time. For the Equatorial Guinean Carlos, as decolonization arrived, "el odio de cómo los primeros blancos habían tratado a los negros surgió, porque debajo había una gran capa de odio y esto preocupaba a los españoles". ${ }^{18}$ Although he

17 "My God, it would be desirable that I'm mistaken. That the Autonomous regime could last for years and that a miracle would make good and trained natives appear.” Ramon Reig. Letter from Oveng-Bata of January 5, 1964, CGF.

18 "the hatred of how the first whites had treated the blacks emerged, because underneath there was a large layer of hate and this worried the Spanish". 
added that a few months before independence "no hubo acciones muy violentas contra la población blanca, pero hubo episodios". ${ }^{19}$ In fact, since suffering under two dictatorships - and because many of them established themselves in the former metropole - not all Equatorial Guineans think of Spain negatively. But it is even more interesting how the Hispano-Moroccan relationship is remembered by many Riffians. In the Rif the false promises made by Franco following his decisive fight with the rebel side of the army and the consequences of the mustard gas were forgotten. They preferred to prioritize Hispano-Moroccan memories as a way of denouncing what they call the current Moroccan occupation, given the poor relationship the region has had with the Alaouite monarchy since its repression of the area from 1958 to 1959 and which since the autumn of 2016 has again become the focus of conflicts (cf. Aixelà-Cabré 2019: 188). Proof of this is that the Riffian Mustapha's relationship with the Spanish population became stronger in the post-colonial period. Other Riffian as Merien and Hamid agreed that Mustapha was "un hombre muy respetado y conocido entre la comunidad española del pueblo". ${ }^{20}$ The Spanish community, in reality, was reinstalled after independence, given that the majority of Spanish settlers had left with the end of the Spanish colonial dream in Morocco. Indeed, the memory of Spain is so strong that Merien and Hamid had trouble distinguishing their memories of the treatment by the Moroccans in the colonial and the post-colonial period, leading them to say "we were better off with the Spanish" ("Estábamos mejor con los españoles)", despite the fact that for the Moroccan Dahbia, "los españoles hicieron barbaridades como el uso del gas mostaza. Pero se ha olvidado interesadamente y hoy se conecta mejor con el pasado español que con el presente marroquî". ${ }^{21}$

The reality is that none of the Spaniards wanted that colonization ended, conscious that colonial independences would suppress their privileges, forcing to leave if they could not adapt to the new situation. For Pepe, Moroccan independence arrived from one day to another, and qualified the moment as a shame:

Mis padres salieron como la mayoría, mal. El gobierno español se preocupó de militares y funcionarios [...] pero a los demás que hicimos el verdadero Marruecos, [...] nos dejaron abandonados [...] Por disposición de los marroquíes mis padres tuvieron que salir a las 5

19 "there was no seriously violent action against the white population, but there were episodes". 20 "highly respected and well-known man in the village's Spanish community".

21 "the Spanish committed outrages like using mustard gas. But in their own interest they have forgotten and today connect better with the Spanish past than with the Moroccan present”. 
de la mañana de Alhucemas con el dinero que habían escondido de sus bienes y de vender el negocio y la casa. ${ }^{22}$

The emotions were similar for the Spaniards of Equatorial Guinea. Eduard was very clear about the Reig family's return, sure that they did not want to come to Barcelona: "Si no hubiese habido lo de la autonomía y lo de la independencia, los Reig no se habrían marchado nunca de Guinea!"23 In fact, Ramon himself wrote in one of his last letters, in a very sad tone: "Al final de este negocio y de toda una vida en África es si no sale algo raro a última hora es que emprenderemos nuestro último viaje desde estas tierras en el [barco] Pamplona que saldrá después del veinte de junio". 24 It was May 1965. Equatorial Guinea proclaimed its independence three years later, October 1968. In March 1969, with the establishment of Macias' dictatorship, the majority of Spaniards had left the country, as did other European and African populations.

\section{The other side of the coin. Africans: Between Spanish militaries and metropolitan benefits}

There can be no doubt that the military's role was decisive in this long colonial journey to maintain Spanish dream of a colonial empire in Africa. The military presence made the territorial occupation obvious and had effects on the whole population. Under the slogan "todo por la patria", the soldiers exerted pressure on the indigenous and Spanish populations, causing violent confrontations, sometimes with Moroccans and others with Spaniards. For Juan, "el ejército actuaba de forma insultante" ("the army acted in an insulting manner.") So much was this true that some people like Juan considered that the troops were the first colonial agents because they "no solo colonizaron a los nativos, también a los españoles" ("not only colonized the natives, but also the Spaniards.").

22 "My parents came out as most, badly. The Spanish government cared about the military and officials [...] but the others that we did the real Morocco [...] left us abandoned [...] By disposition of the Moroccans, my parents had to leave at five o'clock in the morning from Alhucemas with the money that they had hidden after selling the business and the house."

23 "If there had not been autonomy and independence, the Reig would never have left Equatorial Guinea!"

24 "The end of this business and of a whole life in Africa, if something strange does not come out, is that we will undertake our last trip from these lands in the [ship] Pamplona." Ramon Reig. Letter from Oveng-Bata of May 2, 1965, CGF. 


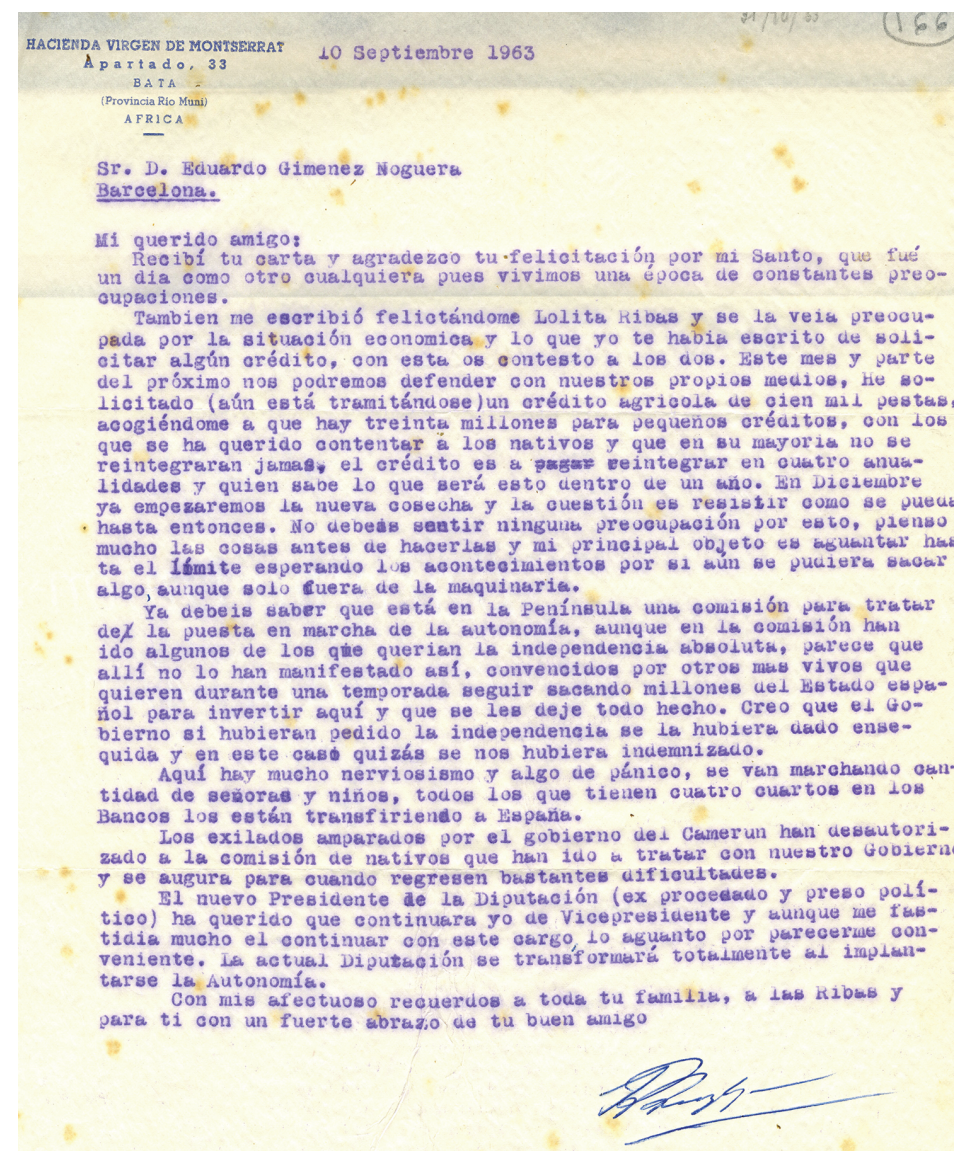

Figure 2: Letter of Ramon Reig from Oveng-Bata (September 10, 1963). Colección Giménez Ferrer (IMF-CSIC).

Military jobs included the consolidation and protection of the area, the maintenance of public order and the imposition of colonial regulations. In Morocco, high-ranking officials such as intervenors (interventores) had great responsibility and knowledge of the land and peoples they controlled, to the extent that a minority developed a degree of empathy for the Moroccans (cf. Villanova 2006: 93). In Spanish Guinea, the issue was entirely different. It is likely that the difference was that Morocco was a protectorate that apparently respected dialogue with the Moroccans themselves at the various state levels -although ultimately they had no autonomy or decision-making capacity- while the Spanish Territories of the Gulf of Guinea had the status of a colony, which meant direct control of the institutions and society. 
But, these differences notwithstanding, in each colony there were regular Moroccan and Equatorial Guinean troops who, despite their different duties, acted as auxiliary Spanish forces and were led by Spaniards. So, while in the Protectorate an attempt was made to respect the independence of certain Moroccan positions without interference, in practice the final word was always Spanish, so that figures such as the Pasha of Al-Hoceima would see their civil, religious or political authority cut in practice, as well as their legislative, executive and judicial power, as Spanish informants confirmed.

But the legacy of the material infrastructure and services constitutes irrefutable colonial evidence, as both Riffians and Equatorial Guineans are well aware and recalled with nostalgia. These improvements, which were essential to justify the European presence and the Spanish civilizing action, allowed the territory to be controlled and exploited; but the educational and healthcare services were very limited and had only a debatable impact, meaning that the facts transcended the civilizing colonial rhetoric.

The establishment of the educational system was slow and late. In Equatorial Guinea it was delegated to the missionary commands, while in the Protectorate it depended directly on the Spanish state, although there were also missionary schools such as the Divina Infantita. The education of Equatorial Guinean boys and girls fell entirely to missions such as the Claretians and Conceptionists, who were established and extended across the island of Fernando Pó (cf. Pujadas 1983: 108). Their activity on the mainland was postponed until well into the 20th century due to the lateness of its effective colonization. The aim of the missions was to Christianize, but schooling allowed direct influence over young people in the hope of reaping the returns in the following generations. The metropole was interested in education because, as well as fulfilling commitments to spreading Catholic activity, it was able to Spanishize the Equatorial Guinean children with the aid of books sent from the peninsula. The success of education as an activity that was appreciated by many Equatorial Guineans led to attempts to get their descendants to study in Spain, and an informal missionary channel was opened up towards the peninsula which comprised a few dozen people each year. The legal changes of provincialization and autonomy meant a qualitative change that encouraged grant calls to appear from the Spanish state for both girls and boys, although in general the provision was extremely limited. With these study grants, Spain hoped to be able to form a select group of Equatorial Guineans who were sympathetic to Spain and would defend its interests when the country obtained independence. Almost without exception, most Equatorial Guinean accounts considered studying 
in Spain to be a genuine escape valve, even if the supply was far smaller than the demand. ${ }^{25}$

The same system of study grants was also extended to the Spanish Protectorate, overlapping in the Rif with the minority who were able to study in the various rural mosques, which despite teaching them to recite some surahs from the Koran in no way guaranteed that they learned to read and write classical Arabic. Until the end of the 1940s, only a few sons of Moroccan potentates based in Al-Hoceima would have studied in Spanish schools. In contrast to Guinea, where the Equatorial Guinean girls were educated (cf. Negrín-Fajardo 2011: 114), in Morocco the Arab and Amazigh were not, though it is worth remembering that Spanish girls faced the same problem: in the Protectorate, the Spanish attended training for "their work" with the nuns from the Divina Infantita, while the Riffians remained illiterate.

With regard to the healthcare system, it may be said that it was established little by little. In general, the Spanish settlers feared more for their health in the Spanish Territories of the Gulf of Guinea than in Morocco. In Al-Hoceima, while the military hospital was being built, the lack of hospitals and doctors was eased by the rapid creation of a dispensary in the Divina Infantita, but both services were aimed mainly at the settler population, as Moroccan attendance took some time to spread. ${ }^{26}$ In Guinea, the slowness and precariousness with which minimal medical infrastructure was set up meant that the Spanish population brought "medicación de primeros auxilios y mucha quinina para tratar las enfermedades tropicales, mientras que las afecciones médicas más graves se trataban directamente en España si la enfermedad permitía el viaje", as Eduard confirmed. ${ }^{27}$ The absence of hospitals there was so evident, and the spread of the plantations so notable that the medical services fell to the doctors. For example, in the documentation of the Colección Giménez Ferrer of Oveng's plantation (mainland region), medical services expenses appear, including those for the braceros under the heading "Medical retainer", ${ }^{28}$ although the African braceros preferred the Equatorial Guinean healers.

25 For example, the Barcelona newspaper La Vanguardia reported on meetings between Equatorial Guinean students in the city in 1962. See La Vanguardia, 17th June 1962, p. 21: “Agasajo a directivos de la casa de Guinea”. The report explains how over 70 people, including Equatorial Guinean students, met in the Centro Guineano.

26 The first years were the most difficult as Rhimou explained. During a pediatric emergency in a Riffian douar Rhimou was attended by a Spanish who ended up leaving her (i.e. Rhimou's) newborn baby lame.

27 "first-aid supplies and a lot of quinine to handle the tropical diseases, while the most serious medical conditions were treated directly in Spain if the illness permitted the journey".

28 This item cost 5,600 pesetas in the second quarter of 1961. CGF, accounts of the Hacienda Virgen de Montserrat in 1961. 
A clear indication that Spanish colonization was being recalled more positively with the passing of the decades was that the memories of the colonial past appeared to be softened in the interviews with Riffians and Equatorial Guineans. Maybe it was because their memory gave greater weight to infrastructure than to personal experiences built over asymmetrical relations observed in the narratives of the Spanish colonial dream.

The current stagnation in investment in infrastructure leads to a part of them to conclude that after colonization a decline occurred in their living conditions. This perception was shared by a big part of Equatorial Guinean population given that following colonization they entered a spiral of dictatorships that continues to the present day (cf. Cusack 1999: 63, 74). In the Moroccan case, it cannot be generalized to the whole Protectorate, but it does apply to a part of the population of the Rif, as this area was left out of current state planning. That is why, when the investment in infrastructure of the respective post-independence era states is compared, Riffians and Equatorial Guineans concluded with nostalgia that at least the Spanish colonizations produced investment. Merien stated that “¡Estábamos mejor con los españoles! Mucho mejor que ahora! Antes de que llegaran los españoles, no había caminos en las montañas, apenas pistas, sólo caminos, los españoles hicieron todo eso. Y cuando los españoles se marcharon, ¡todo se detuvo!" 29 It was the same with many Equatorial Guineans, such as Pablo, for whom "los españoles construyeron caminos, calles, pusieron el alumbrado, las alcantarillas, pero tras la independencia llegó la dictadura y todo se acabó" ${ }^{30}$ So, the precarious life of Riffians and Equatorial Guineans today, combined with an insufficient work done to save their colonial memories and past experiences, pushed them not to criticize excessively Spanish colonial dream and heritage in their lands, expressing a kind of nostalgia with similarities to those expressed by Spaniards: behind a Spanish colonial dream that came true only for Spaniards, some Riffians and Equatorial Guineans appreciated material legacies. To be marginal became a constant feature in their history.

29 "We were better off with the Spanish!! Much better off than now!!! Before the Spanish arrived, there were no roads in the mountains, barely even tracks, only paths, the Spanish did all of that. And when the Spanish went, everything stopped!!”

30 "the Spanish built the roads, the streets, put in the street lighting, the sewers, but after independence dictatorship arrived, and everything ended". 


\section{Concluding words}

The objective of this chapter was to show that the image of economic paradise of the Spanish colonial dream in Africa was possible thank to the power exercized against Africans. This colonial dream can be traced by the emotions expressed by Spaniards during their settlement in Africa and had clear gendered differences. Their emotions transmitted in their memories reinforcing them individual and collectively, abounded men and women satisfaction of colonial past, and their bitterness of leaving their "African" lives behind. The memories of the Spanish civilian who sighed with nostalgia their past in Africa, whatever was their sex or social position in the colony, was confirmed by their emotions of insecurity and loss when they recalled the independence processes. And although Spanish voices corroborated the absent equity between Spaniards and African populations, their memories confronted to some African voices, showed strong experiences questioning emotional self-storytelling of Spanish "generous cohabitation". Surprisingly there were Africans that feel related to the Spanish colonial dream and civilian's nostalgia given their current precarities in sanitary, educative and political systems. For me, this recognition to certain colonial imprints must be understood as their way to express disappointment with their current political system.

The truth is that the Spanish colonial dream in Africa as colonizers was full of emotions, so much so that there are strong connections between narrated memories and felt sentiments. Nostalgia defined their experiences and emotions, although research showed that men and women did not feel equally concerned with this colonial dream, despite when it came true, both, men and women, enjoyed of their numerous advantages. Moreover, Spanish colonial dream was a topic deeply male, not female: while Spanish men saw African conquer and settlement as a true challenge, Spanish women accepted their fate and role more as wives and daughters than as active colonizers. Spanish colonial dream was thus a male project, not female, while the power and authority enjoyed by Spaniards in the colonies would be determinant to reach their satisfaction.

The marginalization of these African populations during colonization could not be reversed currently given the precarious sociopolitical scene that the Rif region and the whole Equatorial Guinea still suffer today. This is why between some African informants emerged a sentiment of nostalgia. Maybe the Spanish colonial dream left direct benefits to Spaniards, becoming the key element to support their successful narrative, but at the same time some Africans rescued their positive effects talking too of nostalgia. Dream and nostalgia finally appeared as two concepts that helped to explain the complex Spanish colonial memories of its African colonies and its impact in the African populations, being bitterness and shame the emotions that dominated Spaniards who felt abandoned by Spain. 


\section{Bibliography}

\section{Primary sources}

\section{Interviews cited}

CARLOS. He was born in Santa Isabel in 1961. He is sociologist and lives in Barcelona. Different interviews in Barcelona from June 2014 to the present.

DAHBIA. She was born in Yerada province (Morocco) in 1977. She is philologist and lives in Rabat. Different interviews in Rabat, Sevilla and Barcelona from May 2015 to the present.

EDUARD. He was born in Barcelona in 1939. His parents were co-owners of a plantation of coffee in Oveng, Bata district, Equatorial Guinea. Owner of the Collection Giménez-Ferrer, ceded to Institució Milà I Fontanls del CSIC (Barcelona). Different interviews in Barcelona from November 2015 to the present.

HAMID. He was born in Einsolen (Morocco) in 1961. He got married in Al-Hoceima with a parallel cousin, and migrated to Catalonia in the 1980s. He lives between Al-Hoceima and Barcelona province. Different interviews in Barcelona province and Al-Hoceima from 2001 to the present.

IRMINA MARgEnAT. She was born in Barcelona. She went with her husband Ramon Reig to Oveng, Bata district, Equatorial Guinea. For this work, I have analyzed the letters she sent from Equatorial Guinea to Barcelona. Collection Giménez-Ferrer, ceded to Institució Milà I Fontanls del CSIC (Barcelona).

MARÍA. She was born in Al-Hoceima (Morocco) in 1936, where she remained until the 1960 s. She lives in Alicante and is 81 years old. She was interviewed in Alicante in May 2016.

MERIEN. She is 50 years old. She was born near Al-Hoceima (Morocco) in 1967. She has lived in Barcelona province from 1998 and travels once time year to visit her mother in AlHoceima. Different interviews in Barcelona province from 2002 to the present.

PABLo. He was born in Malabo (Equatorial Guinea) in 1958. He had worked in a plantation. He was interviewed in Malabo in July 2009.

PEPE. He was born in Melilla (Morocco) in 1931 and lives in Almería. His parents were part of the first civil Spanish people established in Al-Hoceima. He left Morocco in 1957 and never returned. Different interviews in Almeria and Barcelona from November 2015 to June 2018.

RAMON REIG. He was born in Barcelona. He was main responsible and co-owner of a plantation of coffee in Oveng, Bata district, Equatorial Guinea. For this work, I have analyzed the letters he sent from Equatorial Guinea to Barcelona Collection Giménez-Ferrer, ceded to Institució Milà I Fontanls del CSIC (Barcelona).

RHımou. She was born near Al-Hoceima in 1946. Different interviews in Casablanca from June 1993 to August 1997.

\section{Archives consulted}

ArChivo General de la Administración (AGA), Alcalá de Henares. Dirección General de Marruecos

[(15) 3] and archives del Alto Comisionado [(15) 13]. 
ColecCIÓn GIMÉnez FerRer (CGF). Institució Milà i Fontanals, CSIC, Barcelona. This archive constitutes the documentation of the Hacienda Virgen de Montserrat in Oveng-Bata (continental region of Spanish Guinea), established in 1927. This Hacienda Virgen de Montserrat coffee plantation was created by different Catalan and Canary partners and ceased to be operational in 1965, although the lands were legalized in the $1990 \mathrm{~s}$ under the Obiang dictatorship, as an essential procedure to request compensation from the Spanish and Equatorial Guinean governments. The collection includes more than a hundred letters written by Ramon Reig and Irmina Margenat.

\section{Secondary sources}

Aixelà-Cabré, Yolanda (2017): “Exploring Euro-African Pasts through an Analysis of Spanish Colonial Practices in Africa (Morocco and Spanish Guinea)." In: Canadian Journal of African Studies / La Revue canadienne des études africaines 51.1, pp. 23-42.

Aixelà-Cabré, Yolanda (2019): "Colonial Memories and Contemporary Narratives from the Rif. Spanishness, Amazighness, and Moroccaness seen from Al-Hoceima and Spain." In: Interventions. International Journal of Postcolonial Studies 21.6, pp. 856-873.

Appadurai, Arjun (1990): “Disjuncture and Difference in the Global Cultural Economy." In: Theory, Culture \& Society 7.2-3, pp. 295-310.

Calderwood, Eric (2018): Colonial al-Andalus. Harvard: Harvard University Press.

Cusack, Igor (1999): “Being away from 'Home’: The Equatorial Guinean Diaspora.” In: Journal of Contemporary African Studies 17.1, pp. 29-48.

Deckard, Sharae Grace (2010): Paradise Discourse, Imperialism and Globalization. Exploiting Eden. London/ New York: Routledge.

Delgado, Luisa Elena / Fernández, Pura / Labany, Jo (eds.) (2016): Engaging the Emotions in Spanish Culture and History. Nashville: Vanderbilt University Press.

Fernández Moreno, Nuria (2018): “Colonial Discourse and Native Resistance. The Evangelization of Bioko Island in the Early 20th Century (Equatorial Guinea)." In: Aixelà-Cabré, Yolanda (ed.): In the Footsteps of Spanish Colonialism in Morocco and Equatorial Guinea. Zürich: Lit Verlag, pp. 71-99.

Goikolea-Amiano, Itzea (2018): “Hispano-Moroccan Mimesis in the Spanish War on Tetouan and its Occupation (1859-62)." In: The Journal of North African Studies 24.1, pp. 44-61.

Instituto Nacional de Estadística (1952): Territorios españoles del Golfo de Guinea. Censo de 1950. Tomo I. Cifras generales.

La Vanguardia (1962/06/17): “Agasajo a directivos de la casa de Guinea.” In: La Vanguardia, p. 21.

Negrín-Fajardo, Olegario (2011): “QQué queda en Guinea Ecuatorial de la educación española? De la educación colonial a la realidad actual.” In: Historia de la educación: Revista interuniversitaria 30, pp. 111-126.

Pujadas, Tomás L. (1983): La iglesia en la Guinea Ecuatorial. Río Muni. Barcelona: Ed. Claret. Resúmenes Estadísticos del Gobierno General de los Territorios españoles del Golfo de Guinea. 1956-1957 (1958). CSIC: Madrid.

Rosaldo, Renato (1989): “Imperialist Nostalgia.” In: Representations 26, pp. 107-122. 
Sá, Ana Lúcia (2018): “The Construction of the Image of the Indígena in the Spanish Territories of the Gulf of Guinea (1904-1912)." In: Aixelà-Cabré, Yolanda (ed.): In the Footsteps of Spanish Colonialism in Morocco and Equatorial Guinea. Zürich: Lit Verlag, pp. 101-125.

Sánchez Gómez, Luís Ángel (2006): “África en Sevilla: la exhibición colonial de la Exposición Iberoamericana de 1929." In: Hispania 66.224, pp. 1045-1082.

Stoler, Anne L. (1989): “Making Empire Respectable: The Politics of Race and Sexual Morality in 20th-Century Colonial Cultures." In: American Ethnologist 16.4, pp. 634-660.

Villanova, José Luis (2006): Los interventores. La piedra angular del Protectorado español en Marruecos. Barcelona: Bellaterra.

Villanova, Royo (1922): “Introducción.” In: Revista Hispano-Africana. Liga Africanista Española 1, p. 1. 